\title{
Approaches to the treatment of anaemia in patients with chronic heart failure
}

\author{
Clare L. Murphy · John J. V. McMurray
}

Published online: 8 April 2008

(C) Springer Science+Business Media, LLC 2008

\begin{abstract}
An association between anaemia, poor functional status and, compared to non-anaemic patients, worse clinical status and a higher risk of hospitalisation and death has been consistently reported in chronic heart failure (CHF), although cause an effect has not been proven. While it is attractive to think that correction of a co-morbidity that exacerbates already diminished delivery of oxygen to the tissues in heart failure is likely to beneficial, the possible haemodynamic effects of increasing haemoglobin, for example vasoconstriction, might not be. Consequently, the balance of benefit and risk of anaemia correction in CHF is uncertain, may vary according to the severity of anaemia (and other factors) and needs to be properly evaluated. To date, most studies of anaemia correction in CHF have used erythropoiesis stimulating agents (ESAs). The trials with erythropoietin have been of small size, uncontrolled or unblended/single blind, raising concerns again about interpretation of subjective outcomes. In addition, the analyses of these trials have been suboptimal. Two double-blind, placebo-controlled, darbepoetin studies have been published in full. Neither showed an improvement in functional capacity or consistent effect on patient reported symptoms/quality of life. Darbepoetin is, however, currently being tested in a large-scale, phase III morbidity and mortality trial, the Reduction of Events with Darbepoetin alfa in Heart Failure (RED-HF) which should contribute important information of the safety and efficacy of ESAs in this syndrome. Other approaches, notably parenteral iron supplementation, are also being evaluated and other agents for anaemia correction are under development.
\end{abstract}

C. L. Murphy · J. J. V. McMurray ( $₫)$

BHF Cardiovascular Research Centre, University of Glasgow,

126 University Place, Glasgow G12 8TA, Scotland, UK

e-mail: j.mcmurray@bio.gla.ac.uk
Keywords Rationale for treatment of anaemia

\section{Rationale for treatment of anaemia}

Anaemia results in reduced oxygen delivery to the metabolising tissues, sets in train an array of neurohumoral, cardiovascular and renal responses and causes dyspnea, fatigue and oedema [1-3]. Indeed, the fundamental problem (reduced oxygen delivery), the pathophysiologic responses and the symptoms and signs of anaemia closely (but not exactly) mirror those in chronic heart failure (CHF) [1-3]. Some differences exist; for example, anaemia is associated with vasodilatation whereas CHF is characterised by vasoconstriction [1-3].

An association between anaemia, poor functional status and, compared to non-anaemic patients, worse clinical status and a higher risk of hospitalisation and death has been consistently reported in CHF, although cause an effect has not been proven [3, 4-15].

It is, however, easy to believe that correction of a comorbidity that exacerbates already diminished delivery of oxygen to the tissues in heart failure is likely to beneficial although the possible haemodynamic effects of increasing haemoglobin, for example vasoconstriction, might not be [2]. Consequently, the balance of benefit and risk of anaemia correction in CHF is uncertain, may vary according to the severity of anaemia (and other factors) and needs to be properly evaluated.

\section{Aetiology as a basis for treatment}

It seems logical that the treatment of anaemia in CHF should be based upon some understanding of its aetiology. 
Surprisingly, although we know much about the prevalence and prognostic importance of anaemia in these patients, we know very little about its causation. We think the aetiology of anaemia in $\mathrm{CHF}$ is multifactorial, with impaired iron metabolism, bone marrow suppression by pro-inflammatory cytokines, inadequate erythropoietin production and blunted response to erythropoietin in the bone marrow among the suspected culprits [6,10,16-22]. Other potential candidates include renal dysfunction, salt and water retention causing haemodilution and the use of drugs such as antiplatelet and anticoagulant agents which increase the risk of blood loss from the gastrointestinal tract [6, 10, 16-22]. Angiotensin converting enzyme (ACE) inhibitors and angiotensin receptor blockers (ARBs) are also thought to reduce haemoglobin concentration by reducing EPO secretion. The ACE inhibitors also prevent the breakdown of the naturally occurring haematopoiesis inhibitor $N$-acetyl-seryl-aspartyl-lysyl-proline (AcSDKP) [10, 23-27]. Given this potential complexity of causation, it will be fortunate if any single treatment is effective in all or even the majority of patients. Replacement of haematinic factors in deficient patients might be sufficient for many. Despite this, the focus of treatment of anaemia in $\mathrm{CHF}$ to date has been on erythropoiesis stimulating proteins (ESPs), particularly erythropoietin.

\section{Erythropoietin}

Erythropoietin is a glycoprotein growth factor produced mainly by the peritubular cells of the renal cortex its production is stimulated by tissue hypoxia when renal function is intact [28]. Erythropoietin acts by binding to a specific receptor on the cell surface where it then regulates the production of red blood cells. Plasma erythropoietin levels increase exponentially with decreasing haemoglobin concentration.

\section{Erythropoietin in CHF}

Erythropoietin is probably increased in CHF in response to tissue hypoxia, although, apparently, not to the levels appropriate for the level of haemoglobin [20]. This mismatch between erythropoietin and haemoglobin may be because erythropoietin production is impaired in $\mathrm{CHF}$ or because there is erythropoietin resistance in the bone marrow (or both) $[6,10,16-22]$. The chronic renal impairment that often accompanies CHF may also play a role, as a part of the pathophysiological "vicious cycle" that has been named the cardio-renal-anaemia syndrome [29].

\section{Effects of exogenous erythropoietin}

The most obvious effect of erythropoietin is to increase haemoglobin and thereby oxygen delivery to the tissues.
This action, however, has other consequences, including an increase in blood viscosity, peripheral resistance and, probably, blood coagulation (possibly related to an increase in platelet count) [2]. The starting, target, achieved (the latter two often differing) and change in haemoglobin may also be important in determining the net effect of treatment. Higher targets will usually require greater doses of erythropoietin, further complicating evaluation of the treatment intervention. Related to this are the possible additional effects of erythropoietin reflecting the wide repertoire of actions attributed to this complex hormone and growth factor [28, 30, 31]. Furthermore, in rare cases, patients can develop antibodies to the synthetic erythropoietin which cross react with the patient's own naturally occurring erythropoietin which cause life threatening pure red cell aplasia. Finally, ESPs are rarely used alone and, usually, concomitant iron therapy is given; the benefits and risks of iron in patients with $\mathrm{CHF}$ are also unquantified [32]. Consequently, the net effect (reflecting the sum of potentially beneficial and potentially harmful actions) of treatment regimens using erythropoietin (or other synthetic ESPs) is difficult to predict and needs to be determined in appropriated designed, powered, conducted and analyzed clinical trials [33].

\section{Studies of erythropoietin as a treatment for CHF}

The first study reporting the use of exogenous erythropoietin to correct anaemia in patients with CHF was published by Silverberg and colleagues in 2000 [34]. These investigators treated 26 patients for a mean of $7.2 \pm 5.5$ months with subcutaneous erythropoietin (mean dose 5,277 IU/ week) and intravenous iron sucrose (mean dose $185 \mathrm{mg} /$ month) with the intention of raising haemoglobin concentration to $12.0 \mathrm{~g} / \mathrm{dl}$. All patients had severe resistant $\mathrm{CHF}$, despite maximal $\mathrm{CHF}$ treatment for 6 months, and coexistent anaemia. In this unblinded, uncontrolled, study, mean haemoglobin increased from 10.2 to $12.1 \mathrm{~g} / \mathrm{dl}$ with erythropoietin treatment. Compared to before treatment, left ventricular ejection fraction (LVEF) increased and NYHA class, dose of diuretic required, rate of decline in GFR and rate of hospitalisation were all lower, after treatment. Although interesting, it is difficult to interpret or draw any conclusions from these findings in the absence of a control group.

The same investigators published the result of a further study [35] in 2001 in which 32 patients with anaemia (haemoglobin 10-11.5 g/dl) were randomised to no treatment $(n=16)$ or to subcutaneous erythropoietin $(n=16$; $4000 \mathrm{IU}$ once to three times/week) and intravenous iron sucrose (200 mg every 2 weeks) aimed at increasing haemoglobin to at least $12.5 \mathrm{~g} / \mathrm{dl}$ (the actual increase in the 
erythropoietin group was from 10.3 to $12.9 \mathrm{~g} / \mathrm{dl}$ ). All patients had NYHA class III or IV CHF and a LVEF $\leq 40 \%$. Over the mean follow-up period of $8.2 \pm 2.6$ months, the investigators found that, as in their first study, there was a significant improvement in both cardiac and patient function over the course of the study in patients treated with erythrpoietin. LVEF and NYHA class improved, renal function remained static and patients' requirement for diuretics decreased. There were no $\mathrm{CHF}$ related deaths in the erythropoietin-treated group and four CHF-related deaths in the untreated group. Once again, however, the small numbers of subjects, subjective outcomes and lack of blinding make these findings difficult to interpret.

In 2003, Mancini and colleagues [36] published the results of a single-blind (patient-blind) study in which 26 patients with NYHA class II-IV CHF, anaemia (haematocrit $<35 \%$ ) and a baseline plasma erythropoietin level $<100 \mathrm{mU} / \mathrm{ml}$ were randomised $2: 1$ to treatment with 15,000-30,000 IU of erythropoietin per week (adjusted to raise haematocrit to $>45 \%$ ) or to placebo, for a duration of 3 months. Patients randomised to erythropoietin were also prescribed ferrous gluconate $325 \mathrm{mg}$ daily and folate $1 \mathrm{mg}$ daily. Haemoglobin increased from $11.0 \pm 0.6$ to $14.3 \pm 1.2 \mathrm{~g} / \mathrm{dl}$ in the erythropoietin group. There was a significant improvement in peak $\mathrm{VO}_{2}$ uptake in the erythropoietin group, but not in the placebo group (peak $\mathrm{VO}_{2}$ increased from $11 \pm 0.8$ to $12.7 \pm 2.8 \mathrm{ml} \mathrm{kg}^{-1} \mathrm{~min}^{-1}$; $P<0.05$ in the erythropoietin group but declined from $10.0 \pm 1.9$ at baseline to $9.5 \pm 1.6 \mathrm{ml} \mathrm{kg}^{-1} \mathrm{~min}^{-1}$ in the placebo group). Minnesota Living With Heart Failure (MLHF) quality of life score and exercise duration (6 min walk test) also improved in erythropoietin-treated patients and the erythropoietin therapy itself was well tolerated. Interestingly, resting and post-ischaemic forearm vascular resistance was not altered by treatment with erythropoietin. Although this trial was better designed than the earlier ones, it was still single blind, raising concerns again about interpretation of subjective outcomes. In addition withinrather than between-group significance testing was performed.

\section{Darbepoetin alfa as a treatment for CHF}

Darbepoetin alfa is a long-acting ESP preparation with a threefold longer half life and increased bioavailability compared to erythropoietin. It therefore provides the opportunity of two weekly or even four weekly dosing, simplifying treatment and potentially improving adherence in generally older patients already taking an extensive list of medications. Cleland and colleagues [37] investigated the pharmacokinetics and pharmacodynamics of darbepoetin alfa administered on two occasions, one-month apart, to 30 healthy volunteers and to $33 \mathrm{CHF}$ patients with co-existent anaemia (haemoglobin $\leq 12.5 \mathrm{~g} / \mathrm{dl}$ ), in two randomised, double blind, placebocontrolled studies. In the first study, $0.75 \mu \mathrm{g} / \mathrm{kg}$ darbepoietin, administered subcutaneously or intravenously, were compared in a cross-over study. In the second study, various doses of subcutaneous darbepoietin were compared with placebo. The investigators found that subcutaneous darbepoietin (at a higher dose than $0.75 \mu \mathrm{g} / \mathrm{kg}$ ) given on two occasions one-month apart, was suffice to elevate and maintain the haemoglobin concentration. There were no pharmacokinetic differences between healthy volunteers and CHF patients.

In 2007, Ponikowski and colleagues reported a multicentre, randomised, double-blind, placebo-controlled study in which $\mathrm{CHF}$ patients with anaemia (haemoglobin $\geq 9.0$ to $\leq 12.0 \mathrm{~g} / \mathrm{dl}$ ) and a peak $\mathrm{VO}_{2} \leq 16 \mathrm{ml} / \mathrm{kg} / \mathrm{min}$ were assigned either subcutaneous placebo $(n=22)$ or darbepoetin alfa $(n=19)$ at a starting dose of $0.75 \mu \mathrm{g} / \mathrm{kg}$ every 2 weeks for 26 weeks [38]. All patients were also prescribed 200-300 mg/day of elemental oral iron, unless baseline serum ferritin was $>800 \mathrm{ng} / \mathrm{ml}$. The target haemoglobin was $13.0-15.0$ (and not $>15.5$ ) g/dl. The primary end point was change in peak $\mathrm{VO}_{2}$ from baseline to week 27. Differences (95\% confidence interval) in mean changes from baseline to week 27 between treatment groups were $1.5 \mathrm{~g} / \mathrm{dl}(0.5-2.4)$ for haemoglobin concentration (an increase from 11.8 to $13.9 \mathrm{~g} / \mathrm{dl}$ in the darbepoetin group; $P=0.005), 0.5 \mathrm{ml} / \mathrm{kg} / \mathrm{min}(-0.7$ to 1.7$)$ for peak $\mathrm{VO}_{2}$ $(P=0.40), 45 \mathrm{ml} / \mathrm{min}$ ( -35 to 127 ) for absolute peak $\mathrm{VO}_{2}$ $(P=0.27)$, and $108 \mathrm{~s}(-11$ to 228$)$ for exercise duration $(P=0.075)$. Patients receiving darbepoetin alfa compared with placebo had an improvement in self-reported Patient's Global Assessment of Change (79\% vs. $41 \%, P=0.01$ ) but no significant differences in the Kansas City Cardiomyopathy and MLHF Questionnaire scores. There was no between-group treatment-related difference in B type natriuretic peptide or renal function. In summary, this trial did not confirm the supposed benefits of using an ESP in patients with $\mathrm{CHF}$ and anaemia. This study was notable for being the first with a double-blind and placebo-controlled design and the first with a robust statistical analysis. It was also the first multi (as opposed to single) centre study. The only important limitation was its small size, which may have precluded detection of treatment effects.

In 2007, van Veldhuisen and colleagues reported a multi-centre, double-blind placebo-controlled trial in patients with NYHA class II-III CHF, a LVEF $\leq 40 \%$ and haemoglobin 9.0-12.5 g/dl using darbepoetin alfa as the active treatment [39]. Placebo $(n=55)$ or darbepoetin alfa was given subcutaneously every 2 weeks for 26 weeks at a starting weight adjusted dose of $0.75 \mathrm{mcg} / \mathrm{kg}(n=56)$ or a fixed dose of $50 \mathrm{mcg}(n=54)$, to gradually achieve and 
maintain a target haemoglobin of $14.0 \mathrm{~g} / \mathrm{dl}$. The primary endpoint was rate of rise in haemoglobin during the titration phase. The rate of rise of haemoglobin was similar in the darbepoetin alfa weight-based $(+1.87 \mathrm{~g} / \mathrm{dl})$ and fixed dosing $(+1.64 \mathrm{~g} / \mathrm{dl})$ groups compared to $+0.07 \mathrm{~g} / \mathrm{dl}$ in the placebo group.

Mean haemoglobin rose from $11.5 \mathrm{~g} / \mathrm{dl}$ at baseline to $13.3 \mathrm{~g} / \mathrm{dl}$ at 27 weeks in the darbepoetin groups. There were statistically non-significant trends to an improvement in the combined darbepoetin alfa group compared to placebo for 6 min walk distance $(P=0.074)$ and Patient's Global Assessment score $(P=0.057)$. There was a significant improvement in Kansas City Cardiomyopathy Questionnaire total symptom score (8.2 vs. 1.5 points; $P=0.027)$ but no change in NYHA class, LVEF, and MLHF Questionnaire score. Six deaths occurred in the 110 darbepoetin alfa-treated patients and none in the 55 placebo-treated patients. Other adverse events were similar between groups. In summary, the largest and most robust study to date with an ESP did not show convincing evidence of clinical benefit in patients with CHF and anaemia. It is noteworthy that the achieved mean haemoglobin was lower than the target haemoglobin in both the darbepoetin studies described above.

Results of the Study of Anaemia in Heart FailureHeart Failure Trial (STAMINA-HeFT) have been reported recently [40]. In that study, patients with NYHA class IIIV CHF, an LVEF $\leq 40 \%$, serum creatinine $>3 \mathrm{mg} / \mathrm{dl}$, and haemoglobin concentration ranging from 9.0 to $12.5 \mathrm{~g} / \mathrm{dl}$ were randomised to receive subcutaneous darbepoetin $(n=162)$ or placebo $(n=157)$ every 2 weeks for up to a year. The dose of darbepoetin was titrated to achieve haemoglobin in the range of $14.0 \pm 1.0 \mathrm{~g} / \mathrm{dl}$. Anyone with a serum ferritin $\leq 800 \mathrm{ng} / \mathrm{ml}$ also received $200-\mathrm{mg} /$ day supplements of elemental iron.

The mean baseline haemoglobin concentration was between 11.0 and $11.5 \mathrm{~g} / \mathrm{dl}$ in both groups and rose into the target range after about 3 months in the darbepoetin group.

No significant differences were observed in the primary end point of exercise duration at 27 weeks or in NYHA functional class or quality-of-life scores. Exercise duration did, however, tend to increase more in patients with a greater increase in haemoglobin concentration.

A pooled analysis of STAMINA-HeFT and the study reported by van Veldhuisen et al. suggested that darbepoetin treatment in patients with CHF was not associated with an increase in mortality or morbidity (Table 1), a concern raised by other studies with erythropoietin in chronic kidney disease [40].

Darbepoetin, is currently being tested in a large-scale, phase III morbidity and mortality trial, the Reduction of Events with Darbepoetin alfa in Heart Failure (RED-HF) which complements the existing outcome trials with ESAs
Table 1 Morbidity mortality outcomes in pooled darbepoetin trials [40]

\begin{tabular}{lll}
\hline End point & HR $(95 \% \mathrm{CI})$ & $P$-value \\
\hline All-cause mortality & $0.76(0.39-1.48)$ & 0.418 \\
HF-related hospitalisation & $0.66(0.40-1.07)$ & 0.091 \\
All-cause mortality or & $0.67(0.44-1.03)$ & 0.064 \\
$\quad$ first HF-related hospitalisation & & \\
\hline
\end{tabular}

$\mathrm{HF}=$ heart failure; $\mathrm{HR}=$ hazard ratio

conducted in patients with chronic kidney disease and which will contribute important information of the safety and efficacy of ESAs (Table 2) [33].

\section{Iron metabolism and iron deficiency in heart failure}

Iron deficiency in patients with CHF probably has several aetiological factors including poor dietary intake, malabsorption due to oedema of the bowel wall, blood loss from the gastrointestinal tract as a result of antiplatelet and anticoagulant medication, uraemic gastritis and defective mobilisation of iron due to cytokine activation and the hepatic peptide hepcidin $[6,10,16-22,41]$.

The prevalence of iron deficiency in CHF patients with anaemia varies depending on the methods used for confirming the diagnosis. Weiss and Goodnough recently proposed a classification strategy for anaemia of chronic disease, suggesting that iron deficiency was present if the Tsat was $<16 \%$ and the ferritin was $<30 \mathrm{ng} / \mathrm{ml}$ [42]. Felker et al. [43] showed a prevalence of $21 \%$ in a study of the patients enrolled into the OPTIME-HF clinical trial. At the other end of the spectrum Nanas et al. [44] investigated the causes of anaemia (haemoglobin $<12 \mathrm{~g} / \mathrm{dl}$ for men and $<11.5 \mathrm{~g} / \mathrm{dl}$ for women) in 37 patients hospitalised with advanced, decompensated, heart failure. They performed a thorough investigation of these patients after initial medical stabilisation, including bone marrow aspiration and staining, the test which remains arguably the gold standard investigation for the diagnosis of iron deficiency. Iron deficiency confirmed by bone marrow staining was found to be present in $73 \%$ of their patients [44].

There are theoretical and real concerns about the use of iron as a treatment. Theoretically, exogenous iron can cause free radical formation and oxidative stress [32]. More practically, some formulations of parenteral iron can cause anaphylactic reactions.

\section{Treatment of anaemia in CHF using iron alone}

Bolger and colleagues [45] reported a non-randomised, uncontrolled, study of the treatment of anaemia in patients 
Table 2 Comparison of trials with erythropoietin (adapted from [33])

$\mathrm{Hb}=$ haemoglobin;

GFR $=$ estimated glomerular filtration rate; $\mathrm{BP}=$ blood pressure

a Approximate; now fully recruited

b Projected; recruitment or follow-up still ongoing

c Unless haemoglobin falls below $9 \mathrm{~g} / \mathrm{dl}$

d Assumptions; based on similar/earlier studies

\begin{tabular}{|c|c|c|c|c|}
\hline & $\begin{array}{l}\text { CREATE, } \\
n=603\end{array}$ & $\begin{array}{l}\text { CHOIR, } \\
n=1,432\end{array}$ & $\begin{array}{l}\text { TREAT, } \\
n=4,000^{\text {a }}\end{array}$ & $\begin{array}{l}\text { RED-HF, } \\
n=3,400^{\mathrm{b}}\end{array}$ \\
\hline Study population & CKD & CKD & CKD & $\mathrm{CHF}$ \\
\hline \multicolumn{5}{|l|}{ Inclusion criteria } \\
\hline $\operatorname{GFR}\left(\mathrm{ml} / \mathrm{min} / 1.73 \mathrm{~m}^{2}\right)$ & $15-35$ & $15-50$ & $20-60$ & "Normal" \\
\hline $\mathrm{Hb}$ eligibility & $11-12.5$ & $\leq 11$ & $\leq 11$ & $9-12$ \\
\hline Target $\mathrm{Hb}(\mathrm{g} / \mathrm{dl})$ in treatment arm & $13-15$ & 13.5 & 13.0 & 13.0 \\
\hline Study drug & Epoetin beta & Epoetin alfa & Darbepoetin alfa & Darbepoetin alfa \\
\hline Control arm & Active & Active & Placebo $^{c}$ & Placebo \\
\hline Presence of diabetes & $26 \%$ & $49 \%$ & $100 \%$ & $(30 ?)^{\mathrm{d}}$ \\
\hline Presence of heart failure & $32 \%$ & $23 \%$ & $(30 \% ?)^{\mathrm{d}}$ & $100 \%$ \\
\hline Presence of hypertension & $90 \%$ & $94 \%$ & $(70 \% ?)^{\mathrm{d}}$ & $(40 \% ?)^{\mathrm{d}}$ \\
\hline Baseline systolic BP (mm Hg) & 139 & 136 & $(135-140 ?)^{\mathrm{d}}$ & $(110 ?)^{\mathrm{d}}$ \\
\hline Baseline eGFR $\left(\mathrm{ml} / \mathrm{min} / 1.73 \mathrm{~m}^{2}\right)$ & 24.5 & 27.2 & $(25 ?)^{\mathrm{d}}$ & $(53 ?)^{\mathrm{d}}$ \\
\hline $\begin{array}{l}\text { Number of patients experiencing } \\
\text { a primary cardiovascular endpoint }\end{array}$ & 105 & 222 & $1200^{\mathrm{b}}$ & $\sim 1450^{\mathrm{b}}$ \\
\hline
\end{tabular}

with CHF patients, using only iron, at the end of 2006. They treated 16 anaemic patients (haemoglobin $\leq 12 \mathrm{~g} / \mathrm{dl}$ ) who had stable NYHA class II-III CHF and a serum ferritin $<400 \mathrm{ng} / \mathrm{ml}$. Iron deficiency was present in $44 \%$ of patients using the diagnostic criteria of Tsat $<16 \%$ and ferritin $<30 \mathrm{ng} / \mathrm{ml}$. Patients were treated with intravenous iron sucrose (up to a maximum of $1 \mathrm{~g}$, titrated according to ferritin response) over a 12-day period in the out-patient department. The patients were then followed up for a mean of $92 \pm 6$ days. With treatment, haemoglobin rose from $11.2 \pm 0.7$ to $12.6 \pm 1.2 \mathrm{~g} / \mathrm{dl}(P=0.0007)$. NYHA class, MLHF score and the 6-min walk test all improved, changes in the latter two correlating with changes in haemoglobin concentration. Although the design of this study makes interpretation of the results difficult, the study does suggest that many patients with $\mathrm{CHF}$ and anaemia might have an adequate haemoglobin response to iron alone, without use of an ESA. However, even this conclusion is limited by the small numbers of patients studied and uncertainty about patient selection and how generalisable these findings might be.

The Ferric iron sucrose in Heart Failure study (FERRIC$\mathrm{HF}$ ) was designed to evaluate the effect of intravenous iron sucrose on exercise capacity in iron deficient, anaemic and non-anaemic, $\mathrm{CHF}$ patients with reduced exercise capacity (peak $\mathrm{VO}_{2} \leq 18 \mathrm{ml} / \mathrm{kg} / \mathrm{min}$ ). A total of $35 \mathrm{CHF}$ patients (mean LVEF 29\%) were first stratified according to the presence $(n=18)$ or absence $(n=17)$ of anaemia and then randomised in a 2:1 manner to open label, observerblinded treatment or to placebo [40]. The treatment group received intravenous iron sucrose $200 \mathrm{mg}$ /week during a 4week iron correction phase (definition of iron deficiency was serum ferritin $<100 \mu \mathrm{g} / \mathrm{l}$ or ferritin 100-300 $\mu \mathrm{g} / \mathrm{l}$ and Tsat $<20 \%$ ) and then $200 \mathrm{mg} / \mathrm{month}$ during 3-month maintenance phase. At study completion, ferritin levels, functional class based upon Patient Global Assessment, and NHYA class were all significantly increased in the treatment compared to the placebo group, however, contrary to the above findings of Bolger et al., there were no differences in change in haemoglobin concentration between the treated group and the placebo group. There was a trend to an improvement in $\mathrm{VO}_{2}$ max in the entire group $(P=0.08)$, which corresponded to increase in Tsat, with a greater effect seen in the anaemic as compared to the non-anaemic patients.

Clearly, these two small studies do not tell us anything definitive about the use of iron alone as a treatment for anaemia (and even iron deficiency without anaemia) in heart failure. Nevertheless, they are sufficiently intriguing to suggest that further investigation of this treatment approach is worthwhile. This view is supported by the recent finding that intravenous iron reduces NT pro B type natriuretic peptide concentrations in patients with $\mathrm{CHF}$ and renal impairment [46]. Another study of exogenous iron as a treatment in patients with $\mathrm{CHF}$ and anaemia is underway [47].

\section{Potential future anaemia treatments in heart failure}

The Continuous Erythropoietin Receptor Activator (CERA) is a pegylated ReHuEPO which has a longer elimination half life than epoietin and darbepoietin [48]. Both pre-clinical and clinical studies have shown that it requires less frequent dosing and may also have reduced immunogenicity in comparison to epoietin and darbepoietin and may be as effective in treating anaemia. It is undergoing regulatory review for the treatment of anaemia 
in chronic kidney disease and phase 2 trials are currently underway in cancer patients with anaemia secondary to chemotherapy.

Another novel pegylated synthetic erythropoietin receptor agonist 'Haematide' has recently been developed [48]. It comprises a dimeric peptide, unrelated in sequence to any of the synthetic erythropoietin currently on the market. Early results from small trials show it to be effective at raising and maintaining haemoglobin concentrations and suitable for monthly dosing. It is currently in phase II trials.

Hypoxia-inducible transcription factors (HIF) activate erythropoietin and thus play an important role in the regulation of erythropoiesis, iron mobilisation and utilisation and the survival of red blood cells in hypoxic conditions [49]. HIF activity is negatively regulated by prolyl hydroxylases (PH). Recently inhibitors of HIF-PH have been shown to stabilise HIF resulting in stimulation of erythropoiesis and an increase in haemoglobin concentration [28]. They may have a more comprehensive effect on erythropoiesis than other ESAs through their capacity to stimulate iron mobilisation and to suppress the negative effects of pro-inflammatory cytokines. That they are oral preparations is clearly attractive. These agents are currently in early clinical development.

\section{Conclusions drawn from the evidence to date}

Although anaemia is a rational therapeutic target in the drive to improve morbidity and mortality in patients with heart failure, we have, as yet, no convincing data on efficacy, in terms of symptoms or morbidity-mortality outcomes, or safety, for any treatment. We do not know which is the most appropriate treatment in any individual patient. We do not even know the haemoglobin threshold below which it may be appropriate to start treatment. Even the most commonly tested treatment to date, ESPs, actually reflect a complex regimen usually involving a variable dose of an ESP, iron (the dose of which also varies) and a change in haemoglobin from a certain baseline to a certain achieved concentration, which may or may not match the target concentration. Experience in chronic kidney disease reveals the paradox that some of the patients with the smallest rise in haemoglobin are those that receive the highest dose of ESP and iron (i.e., are "poor responders"). Despite these complexities, the quality of studies in this area have steadily improved over time and we now have a very large morbidity-mortality trial underway which will, hopefully, give the definitive answer on the true benefit to risk ratio for one ESP. Similar high standards of proof will be required of other agents.

\section{References}

1. Anand IS, Chandrashekhar Y, Ferrari R, Poole-Wilson PA, Harris PC (1993) Pathogenesis of oedema in chronic severe anaemia: studies of body water and sodium, renal function, haemodynamic variables, and plasma hormones. Br Heart J 70:357-362

2. Anand IS, Chandrashekhar Y, Wander GS, Chawla LS (1995) Endothelium-derived relaxing factor is important in mediating the high output state in chronic severe anemia. J Am Coll Cardiol 25:1402-1407

3. O'Meara E, Murphy C, McMurray JJ (2004) Anemia and heart failure. Curr Heart Fail Rep 1:176-182

4. Horwich TB, Fonarow GC, Hamilton MA, MacLellan WR, Borenstein J (2002) Anemia is associated with worse symptoms, greater impairment in functional capacity and a significant increase in mortality in patients with advanced heart failure. J Am Coll Cardiol 39:1780-1786

5. McClellan WM, Flanders WD, Langston RD, Jurkovitz C, Presley R (2002) Anemia and renal insufficiency are independent risk factors for death among patients with congestive heart failure admitted to community hospitals: a population-based study. J Am Soc Nephrol 13:1928-1936

6. Tanner H, Moschovitis G, Kuster GM, Hullin R, Pfiiffner D, Hess OM, Mohacsi P (2002) The prevalence of anemia in chronic heart failure. Int J Cardiol 86:115-121

7. Ezekowitz JA, McAlister FA, Armstrong PW (2003) Anemia is common in heart failure and is associated with poor outcomes: insights from a cohort of 12065 patients with new-onset heart failure. Circulation 107:223-225

8. Kosiborod M, Smith GL, Radford MJ, Foody JM, Krumholz HM (2003) The prognostic importance of anemia in patients with heart failure. Am J Med 114:112-119

9. Mozaffarian D, Nye R, Levy WC (2003) Anemia predicts mortality in severe heart failure: the prospective randomized amlodipine survival evaluation (PRAISE). J Am Coll Cardiol 41: 1933-1939

10. Anand I, McMurray JJ, Whitmore J, Warren M, Pham A, McCamish MA, Burton PB (2004) Anemia and its relationship to clinical outcome in heart failure. Circulation 110:149-154

11. Maggioni AP, Opasich C, Anand I, Barlera S, Carbonieri E, Gonzini L, Tavazzi L, Latini R, Cohn J (2005) Anemia in patients with heart failure: prevalence and prognostic role in a controlled trial and in clinical practice. J Card Fail 11:91-98

12. Anand IS, Kuskowski MA, Rector TS, Florea VG, Glazer RD, Hester A, Chiang YT, Aknay N, Maggioni AP, Opasich C, Latini R, Cohn JN (2005) Anemia and change in hemoglobin over time related to mortality and morbidity in patients with chronic heart failure: results from Val-HeFT. Circulation 112:1121-1127

13. Kosiborod M, Curtis JP, Wang Y, Smith GL, Masoudi FA, Foody JM, Havranek EP, Krumholz HM (2005) Anemia and outcomes in patients with heart failure: a study from the National Heart Care Project. Arch Intern Med 165:2237-2244

14. O'Meara E, Clayton T, McEntegart MB, McMurray JJ, Lang CC, Roger SD, Young JB, Solomon SD, Granger CB, Ostergren J, Olofsson B, Michelson EL, Pocock S, Yusuf S, Swedberg K, Pfeffer MA (2006) CHARM Committees and Investigators. Clinical correlates and consequences of anemia in a broad spectrum of patients with heart failure: results of the Candesartan in Heart Failure: Assessment of Reduction in Mortality and Morbidity (CHARM) Program. Circulation 113:986-994

15. Komajda M, Anker SD, Charlesworth A, Okonko D, Metra M, Di Lenarda A, Remme W, Moullet C, Swedberg K, Cleland JG, Poole-Wilson PA (2006) The impact of new onset anaemia on morbidity and mortality in chronic heart failure: results from COMET. Eur Heart J 27:1440-6144 
16. Witte KK, Desilva R, Chattopadhyay S, Ghosh J, Cleland JG, Clark AL (2004) Are hematinic deficiencies the cause of anemia in chronic heart failure? Am Heart J 147:924-930

17. Androne AS, Katz SD, Lund L, LaManca J, Hudaihed A, Hryniewicz K, Mancini DM (2003) Hemodilution is common in patients with advanced heart failure. Circulation 107:226-229

18. van der Meer P, Lipsic E, Westenbrink BD, van de Wal RM, Schoemaker RG, Vellenga E, van Veldhuisen DJ, Voors AA, van Gilst WH (2005) Levels of hematopoiesis inhibitor $N$-acetylseryl-aspartyl-lysyl-proline partially explain the occurrence of anemia in heart failure. Circulation 112:1743-1747

19. Okonko DO, Van Veldhuisen DJ, Poole-Wilson PA, Anker SD (2005) Anaemia of chronic disease in chronic heart failure: the emerging evidence. Eur Heart J 26:2213-2214

20. Westenbrink BD, Visser FW, Voors AA, Smilde TD, Lipsic E, Navis G, Hillege HL, van Gilst WH, van Veldhuisen DJ (2007) Anaemia in chronic heart failure is not only related to impaired renal perfusion and blunted erythropoietin production, but to fluid retention as well. Eur Heart J 28:166-171

21. Westenbrink BD, Voors AA, van Veldhuisen DJ (2007) Is anemia in chronic heart failure caused by iron deficiency? J Am Coll Cardiol 49:2301-2302

22. Berry C, Norrie J, Hogg K, Brett M, Stevenson K, McMurray JJ (2006) The prevalence, nature, and importance of hematologic abnormalities in heart failure. Am Heart J 151:1313-1321

23. Gossmann J, Burkhardt R, Harder S, Lenz T, Sedlmeyer A, Klinkhardt U, Geiger H, Scheuermann EH (2001) Angiotensin II infusion increases plasma erythropoietin levels via an angiotensin II type 1 receptor-dependent pathway. Kidney Int 60:83-86

24. Freudenthaler SM, Schreeb K, Körner T, Gleiter CH (1999) Angiotensin II Increases erythropoietin production in healthy human volunteers. Eur J Clin Invest 29:816-823

25. Pratt MC, Lewis-Barned NJ, Walker RJ, Bailey RR, Shand BI, Livesey J (1992) Effect of angiotensin converting enzyme inhibitors on erythropoietin concentrations in healthy volunteers. Br J Clin Pharmacol 34:363-365

26. Chatterjee B, Nydegger UE, Mohacsi P (2000) Serum erythropoietin in heart failure patients treated with ACE-inhibitors or AT(1) antagonists. Eur J Heart Fail 2:393-398

27. Ishani A, Weinhandl E, Zhao Z, Gilbertson DT, Collins AJ, Yusuf S, Herzog CA (2005) Angiotensin-converting enzyme inhibitor as a risk factor for the development of anemia, and the impact of incident anemia on mortality in patients with left ventricular dysfunction. J Am Coll Cardiol 45:391-399

28. Jelkmann W (2007) Erythropoietin after a century of research: younger than ever. Eur J Haematol 78:183-205

29. Silverberg DS, Wexler D, Blum M, Wollman Y, Schwartz D, Sheps D, Keren G, Iaina A (2004) The interaction between heart failure, renal failure and anemia - the cardio-renal anemia syndrome. Blood Purif 22:277-284

30. Sytkowski AJ (2007) Does erythropoietin have a dark side? Epo signaling and cancer cells. Sci STKE 2007:pe38

31. Westenbrink BD, Lipsic E, van der Meer P, van der Harst P, Oeseburg H, Du Marchie Sarvaas GJ, Koster J, Voors AA, van Veldhuisen DJ, van Gilst WH, Schoemaker RG (2007) Erythropoietin improves cardiac function through endothelial progenitor cell and vascular endothelial growth factor mediated neovascularization. Eur Heart J 28:2018-2027

32. Saglam F, Cavdar C, Uysal S, Cavdar Z, Camsari T (2007) Effect of intravenous iron sucrose on oxidative stress in peritoneal dialysis patients. Ren Fail 29:849-854

33. van Veldhuisen DJ, McMurray JJ (2007) RED-HF Executive Committee. Are erythropoietin stimulating proteins safe and efficacious in heart failure? Why we need an adequately powered randomised outcome trial. Eur J Heart Fail 9:110-112
34. Silverberg DS, Wexler D, Blum M, Keren G, Sheps D, Leibovitch E, Brosh D, Laniado S, Schwartz D, Yachnin T, Shapira I, Gavish D, Baruch R, Koifman B, Kaplan C, Steinbruch S, Iaina A (2000) The use of subcutaneous erythropoietin and intravenous iron for the treatment of the anemia of severe, resistant congestive heart failure improves cardiac and renal function and functional cardiac class, and markedly reduces hospitalizations. J Am Coll Cardiol 35:1737-1744

35. Silverberg DS, Wexler D, Sheps D, Blum M, Keren G, Baruch R, Schwartz D, Yachnin T, Steinbruch S, Shapira I, Laniado S, Iaina A (2001) The effect of correction of mild anemia in severe, resistant congestive heart failure using subcutaneous erythropoietin and intravenous iron: a randomized controlled study. J Am Coll Cardiol 37:1775-1780

36. Mancini DM, Katz SD, Lang CC, LaManca J, Hudaihed A, Androne AS (2003) Effect of erythropoietin on exercise capacity in patients with moderate to severe chronic heart failure. Circulation 107:294-299

37. Cleland JG, Sullivan JT, Ball S, Horowitz JD, Agoram B, Rosser D, Yates W, Tin L, Fuentealba P, Burton PB (2005) Once-monthly administration of darbepoetin alfa for the treatment of patients with chronic heart failure and anemia: a pharmacokinetic and pharmacodynamic investigation. J Cardiovasc Pharmacol 46:155-161

38. Ponikowski P, Anker SD, Szachniewicz J, Okonko D, Ledwidge M, Zymlinski R, Ryan E, Wasserman SM, Baker N, Rosser D, Rosen SD, Poole-Wilson PA, Banasiak W, Coats AJ, McDonald $\mathrm{K}$ (2007) Effect of darbepoetin alfa on exercise tolerance in anemic patients with symptomatic chronic heart failure: a randomized, double-blind, placebo-controlled trial. J Am Coll Cardiol 49:753-762

39. van Veldhuisen DJ, Dickstein K, Cohen-Solal A, Lok DJ, Wasserman SM, Baker N, Rosser D, Cleland JG, Ponikowski P (2007) Randomized, double-blind, placebo-controlled study to evaluate the effect of two dosing regimens of darbepoetin alfa in patients with heart failure and anaemia. Eur Heart J 28:2208-2216

40. Ghali JK, Anand IS, Abraham WT, Fonarow GC, Greenberg B, Krum H, Massie BM, Wasserman SM, Trotman ML, Sun Y, Knusel B, Armstrong P; on behalf of the Study of Anemia in Heart Failure Trial (STAMINA-HeFT) Group (2008) Randomized double-blind trial of darbepoetin alfa in patients with symptomatic heart failure and anemia. Circulation. [Epub ahead of print]

41. Haurani FI (2006) Hepcidin and the anemia of chronic disease. Ann Clin Lab Sci 36:3-6

42. Weiss G, Goodnough LT (2005) Anemia of chronic disease. N Engl J Med. 352:1011-1023

43. Felker GM, Gattis WA, Leimberger JD, Adams KF, Cuffe MS, Gheorghiade M, O'Connor CM (2003) Usefulness of anemia as a predictor of death and rehospitalization in patients with decompensated heart failure. Am J Cardiol 92:625-628

44. Nanas JN, Matsouka C, Karageorgopoulos D, Leonti A, Tsolakis E, Drakos SG, Tsagalou EP, Maroulidis GD, Alexopoulos GP, Kanakakis JE, Anastasiou-Nana MI (2006) Etiology of anemia in patients with advanced heart failure. J Am Coll Cardiol 48: 2485-2489

45. Bolger AP, Bartlett FR, Penston HS, O'Leary J, Pollock N, Kaprielian R, Chapman CM (2006) Intravenous iron alone for the treatment of anemia in patients with chronic heart failure. J Am Coll Cardiol 48:1225-1227

46. Toblli JE, Lombraña A, Duarte P, Di Gennaro F (2007) Intravenous iron reduces NT-pro-brain natriuretic peptide in anemic patients with chronic heart failure and renal insufficiency. J Am Coll Cardiol 50:1657-1665

47. Beck-da-Silva L, Rohde LE, Pereira-Barretto AC, de Albuquerque D, Bocchi E, Vilas-Boas F, Moura LZ, Montera MW, Rassi S, Clausell N (2007) Rationale and design of the IRON-HF study: 
a randomized trial to assess the effects of iron supplementation in heart failure patients with anemia. J Card Fail 13:14-17

48. Macdougall IC (2006) Recent advances in erythropoietic agents in renal anemia. Semin Nephrol 26:313-318
49. Peyssonnaux C, Zinkernagel AS, Schuepbach RA, Rankin E, Vaulont S, Haase VH, Nizet V, Johnson RS (2007) Regulation of iron homeostasis by the hypoxia-inducible transcription factors (HIFs). J Clin Invest 117:1926-1932 